\title{
JURY REPORT ON THE KVS AWARD FOR THE BEST DOCTORAL THESIS IN ECONOMICS OF THE ACADEMIC YEARS 2004/2005 \\ AND 2005/2006
}

In 1999, on the occasion of its 150th anniversary, the Royal Netherlands Economic Association (KVS) instituted the KVS Award to promote the study of economics by young academics. The KVS medal is awarded every two years to the Dutch-university doctorate who has written the best $\mathrm{PhD}$ thesis in economics. The medal comes with a prize of EUR 5.000. The first prize-winner in 2000 was Vincent Buskens for his thesis on Social networks and trust, the second in 2002 was Sander Onderstal for his Papers in auction theory. In 2004, Stefan Wuyts won the award with his thesis on partner selection in business markets.

The faculties of Economics of Dutch universities have made a long-list of nine theses for this year's award. They are considered by their universities to be the top theses that have been defended during the last 2 years.

The nominees (in alphabetical order) and their theses are:

Andrea Galeotti, On Social and Economic Networks;

Robert Inklaar, Perspectives on Productivity and Business Cycles in Europe. Contributions to the Euro and the Lisbon Agenda to Growth;

Michael Kötter, Efficiency and Mergers in German Banking;

Roger Laeven, Essays on Risk Measures and Stochastic Dependence;

Arkadi Predtetchinski, Incomplete Contracts and the Core;

Alfred Slager, Banking Across Borders;

Robert Sparrow, Health, Education and Economic Crisis: Protecting the Poor in Indonesia;

Klaas Staal, Voting, Public Goods and Violence;

Bas van Velzen, Cooperation in networks and scheduling.

The jury, professors Van Damme, Fase, Franses and KVS-chairman Keuzenkamp, had the difficult task to rank those theses, all of them being excellent examples of economic research. The theses cover a broad area of economics, from fundamental micro-economics to an analysis of concentration in banking.

This year, the award will go to Dr. Robert Sparrow, who defended his thesis on the Asia crisis and economic development in Indonesia at the Free University of Amsterdam in 2006. The crisis of 1997 generated a drop of GDP by about 14 percent. This was a serious threat to the steady improvement of the economy during the preceding years. Health and education can be very vulnerable in times of crisis. Therefore, the Indonesian government responded with programs to protect the poor from the crisis. Robert Sparrow evaluates the effectiveness of the interventions by means of modern econometric methods. 
The education program introduced cash transfers to families, conditional on children enrolled in education. The program relied on incomplete information on poverty. As a result, the program was not perfectly targeted. This imperfection, paradoxically, makes good econometric evaluation possible. Sparrow finds that the education program effectively protected access to education by the poor.

The health program involved a subsidy for targeted poor households. The design of this program did not adequately take into account that the subsidy would induce substitution between private and public health care. As a result, in the end the non-poor reaped most of the benefits from the program.

The results of this $\mathrm{PhD}$ thesis are of direct value to crisis management in developing countries. The fact that a summary in Indonesian is added to the Dutch and English summary, shows that the author hopes to influence development policy not only in theory, but also in practice. We believe that this study indeed strongly contributes to our understanding of interventions in development programs. It is therefore with great pleasure that the jury awards the KVS-medal for the best doctoral thesis to Robert Sparrow. We wish him all the best in his further career.

Eric van Damme Martin Fase

Hugo Keuzenkamp

Philip Hans Franses 